\title{
A good day
}

Hoy es un buen día, señora,

I tell her, my eyes betraying my fears

as they had on days before

Her eyes stare through me as she mouths Gracias, Doctor. The very thought of the words causing her to strain against the breathing tube we placed just yesterday, while the amassing weight of her abdomen, filling with blood, crushes what little spirit remains.

I think this will really be it,

I say to the family for what must be the tenth time, half embarrassed to be hopeful while their mother, wife, daughter

lies dying within arms' reach.

We are so lucky the cancer centre accepted her, never mind it took them six weeks.

A massive tumour is not an emergency.

She only has emergency Medicaid.

We have to get emergency approval from the finance office. What could have been more emergent than saving the life and dignity of a woman who has raised six children?

We'll have an answer for you tomorrow

It's because she's undocumented,

the family would half say, half ask, repeating the statement often, sometimes using the word "illegal,"

as if to alternately accept and then eschew blame.

Do you think she'd be okay now if she'd come in sooner?

They give me too much credit as prognosticator, as referee between life and death.

She calls you her angel,

the youngest, at 15 , says as her thumbs glide through the text message she composes,

partly for distraction, partly because she's emerged as the family centre.

El buen doctor es mi ángel, she's always saying.

I smile, mutter something about doing this together.

The sugary words hurt my teeth.

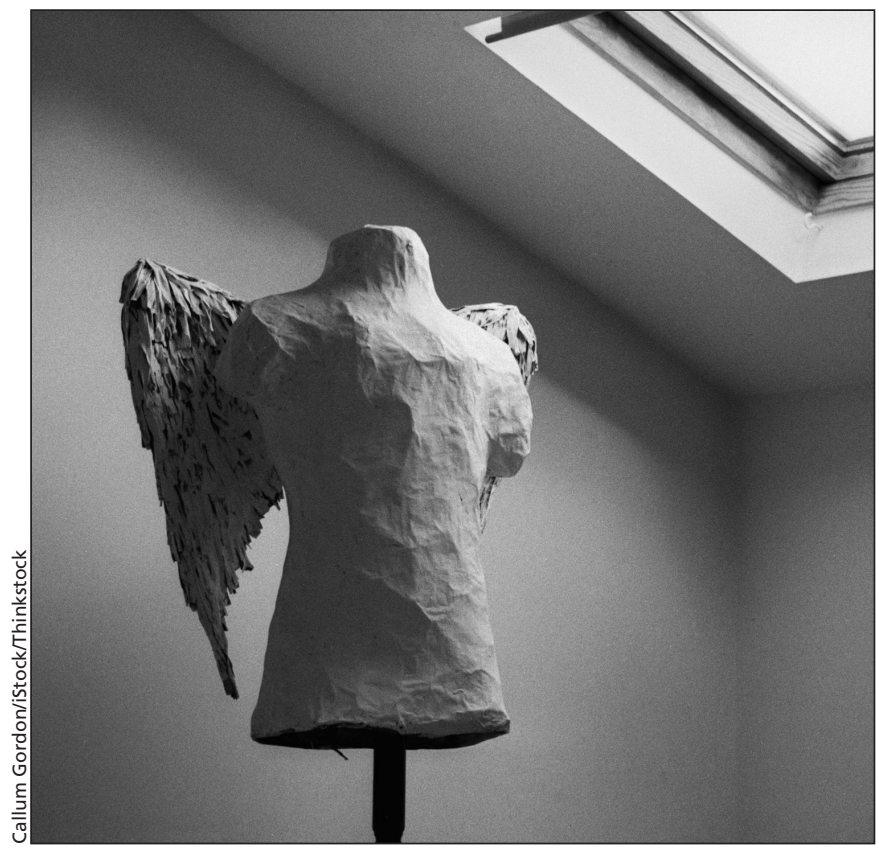

Un buen día,

I repeat with purpose, gripping her hands tightly with mine, urging the diminishing strength from my own body into hers.

The nurse who has known the family for the same six weeks as I

appears with news that the transfer is confirmed.

The paramedics are on their way up.

Air in the room is heavy, even stifling,

but I play my role as doctor, as angel,

give hugs all around,

manage one final "Un buen día,"

before turning to hide tears I would rather not explain.

\section{Scott Edward Nass MD MPA}

Ventura County Medical Center and Santa Paula Hospital

Santa Paula, Calif

CMAJ 2015. DOI:10.1503/cmaj.140663 